\title{
Occupational Health Surveillance: Lung Function Testing in Seafood Workers
}

\author{
THIRUMOORTHY AMARAVATHI ${ }^{*}$, PARAMASIVAM PARIMALAM ${ }^{1}$, \\ GANAPATHYSAMY HEMALATHA ${ }^{2}$ and ANIND KUMAR GANGULI ${ }^{3}$
}

\begin{abstract}
1Department of Family Resource Management, Home Science College \& RI, Madurai, India. ${ }^{2}$ Department of Food Science and Nutrition, Home Science College and RI, Madurai, India.

${ }^{3}$ Senior Deputy General Manager, Bharat Heavy Electricals Limited, Trichy, India.
\end{abstract}

http://dx.doi.org/10.12944/CWE.11.3.18

(Received: August 05, 2016; Accepted: November 12, 2016)

\begin{abstract}
In this study the lung function status of women workers in seafood industry in India (especially in Tuticorin district) were examined. One hundred and five women workers were randomly selected from five seafood-processing units were from peeling, grading and setting sections. Lung function was measured by recording the flow/volume, Slow Vital Capacity (SVC) and Maximum Voluntary Ventilation (MVV) curves on which different static and dynamic parameters were read. The work timings were greatly dependent on the demand for the seafood during the peak season from June to March. Both the static and dynamic values were found to be lower for those with longer period of work experience. Section wise analysis indicated that workers in fish grading section had lower level of static and dynamic parameters. Seventy three percent of women workers had moderate Chronic Obstructive Pulmonary Disease. Total Immunoglobulin E (total IgE) and static and dynamic parameters indicated that the dynamic parameters such as $\mathrm{FEV}_{1}$ and PEF were significantly associated with different levels of total IgE (total immunoglobulin $\mathrm{E}$ ) and the same trend was observed in static parameters of FVC.
\end{abstract}

Keywords: Lung function test, Women workers, Static and dynamic parameters, Immunoglobulin E, Seafood industry.

\section{INTRODUCTION}

Labour tends to be divided along gender lines with men almost exclusively going out to sea to catch the fish and women doing the majority of on-land seafood processing. A considerable proportion of the workforce is seasonal. The degree of exposure to seafood is likely to be highest during the harvest season, which varies according to the seafood type, when most of the processing occurs. Occupational allergic reaction to seafood was first reported by De Besche, when he described a fisherman who developed asthma, angioderma and conjunctivitis when handling codfish ${ }^{1)}$. Work at seafood industry may involve inhalation exposure to a number of bioaerosol components, depending on the processes performed and seafood tissues exposed to the environment. Bioaerosols in seafood industry may comprise proteins, high molecular weight allergens, endotoxin, microorganisms etc ${ }^{2,3}$.

Aerosolisation of the seafood during processing has been identified as a potential high risk activity for immunological sensitisation by high molecular weight proteins, respiratory symptoms, 
non-specific bronchial hyper responsiveness, and work related asthma. These health outcomes are mainly due to high molecular weight protein in seafood causing an $\operatorname{lgE}$ mediated response ${ }^{4,5}$. Serum IgE levels significantly increased in all groups of asthma when compared to control subjects $(p<0.001)$. The IgE levels were proportionately higher in patients with more severe airflow obstruction. The serum IgE level may reflect the severity of bronchial asthma assessed by pulmonary function tests and clinical history ${ }^{6}$.

The adaptive immune response provides specific protection against infection with bacteria, viruses, parasites and fungi. It is able to provide rapid protection against a repeated challenge with the same or similar foreign organism or toxin. By contrast, some immune responses can give rise to an excessive or inappropriate reaction, which is referred to as hypersensitivity. Type I or immediate hypersensitivity is characterised by the production of $1 \mathrm{gE}$ antibodies against foreign proteins commonly present in the environment. These antibodies bind specifically to a high-affinity receptor on mast cells and basophils, which are the only human cells that contain histamine. Subsequent exposure to the same antigens will lead to rapid release of histamine, and more gradual release of other mediators including leukotrines and cytokines ${ }^{7}$. IgE is responsible for the release of various inflammatory mediators in asthma, such as histamine, prostaglandins, and leukotriens. These inflammatory mediators increase airway narrowing due to excessive mucus production, airway smooth muscle spasm, and edema of the airway mucosa ${ }^{8}$.

Occupational asthma is typically from an $\lg \mathrm{E}$ mediated hypersensitivity reaction after respiratory exposure to aerosolised fish and shellfish proteins. It more commonly occurs due to crustaceans, but molluscs and fin fish were implicated as well. Steps to reduce atmospheric allergen concentration in the work place have proven to be preventive of this disease ${ }^{9}$. Bronchial air flow limitation is a major public health concern affecting 100-150 million people worldwide. Elevated total serum immunoglobulin $E(\operatorname{lgE})$ is considered as an objective marker of allergy and has been associated with a number of respiratory disorders.
Hence, systematic Occupational Health and Safety (OHS) research in this industry is an important occupational health hazard prevention tool and but is still in its infancy. The present study portrays the assessment of lung function test.

\section{MATERIALS AND METHODS}

\section{Study subjects and area}

A survey was conducted in the seacoast regions (Tuticorin) of the Southern province of India. This part of India has number of such industries that employ more number of women workers. A peculiar feature of these industries is that majority of them employed in these industries were women. Few male workers were employed as supportive workers. This was the reason of restricting this study to women workers only.

Tuticorin has 91 registered export units and 33 processing plants (MPEDA). For the present study, five industries were selected randomly from a list of all the industries of that area. These industries were selected because of availability of permission for the research, approachable workers for personal interview and convenient transport facilities. The total number of workers in all the five units were 566 who were employed in three sections namely- peeling (151 nos), grading (216 nos) and setting (199 nos). Approximately twenty percent of the sample populations from three sections were selected randomly. Hence 105 women workers from three sections were selected to examine lung function test. Before undergoing the lung function test, the details of the test were explained to the officials of the industry and also to each worker. Following this, a written consent was obtained from all the workers participating in the test. The type of seafoods processed in these industries were shrimp, cuttlefish, squid and octopus. Most of the women workers had to process different type of seafood on need basis.

\section{Assessment of lung function}

A standard questionnaire was used to collect information regarding, age, height, current and previous employment, exposure to seafood and prevalence of respiratory problem (wheeze, cough, cold and chest pain). It was administered by trained interviewer in vernacular language. 
Lung function test was carried out for workers at the worksite using ZAN 100 USB spirometer (Better Flow). American Thoracic Society (ATS) guidelines were followed for spirometry tests ${ }^{10}$. The spirometry calibration (ZAN 100 USB spirometry) was carried out twice a day. Temperature, humidity and time of the day were recorded. For logistical reasons, spirometry tests were conducted during work hours. Prior to the lung function test the women workers were asked to rest for 30 minutes. Lung function tests were performed in the sitting position with nose clip fixed on the nose. Three tests to get flow/volume, Slow Vital Capacity (SVC) and Maximum Voluntary Ventilation (MVV) were conducted for each subject. Each subject underwent the test more than thrice, from which the best result was taken.

Stages of Chronic Obstructive Pulmonary Disease

\begin{tabular}{clll}
\hline S.No & Stage of COPD & ATS/ERS 2004 \\
\hline \multirow{2}{*}{1} & \multirow{2}{*}{ Normal } & FEV1/FVC & $:>0.70$ \\
& & FEV1 & $: \geq 80 \%$ predicted \\
2 & Mild & FEV1/FVC & $: \leq 0.70$ \\
& & FEV1 & $: \geq 80 \%$ predicted \\
3 & \multirow{2}{*}{ Moderate } & FEV1/FVC & $: \leq 0.70$ \\
& & FEV1 & $: 50 \%-80 \%$ predicted \\
4 & \multirow{2}{*}{ Severe } & FEV1/FVC & $: \leq 0.70$ \\
\multirow{2}{*}{5} & \multirow{2}{*}{ Very severe } & FEV1 & $: 30 \%-50 \%$ predicted \\
& & FEV1/FVC & $: \leq 0.70$ \\
& & FEV1 & $:<30 \%$ predicted \\
\hline
\end{tabular}

Abbreviations: FEV1, forced expiratory volume in $1 \mathrm{sec}$; FVC, forced vital capacity.

COPDas defined according to American Thoracic Society [ATS] 2004 Criteria 11)

Table 1: Demographic characteristic of women workers

\begin{tabular}{clcc}
\hline S. & Particulars (N=105) & Sections & Mean \pm SD \\
No & & & \\
\hline \multirow{2}{*}{1} & \multirow{2}{*}{ Age (yrs ) } & Peeling & $19.57 \pm 3.31$ \\
& & Grading & $18.60 \pm 3.23$ \\
\multirow{2}{*}{2} & \multirow{2}{*}{ Work experience (yrs) } & Setting & $18.65 \pm 2.87$ \\
& & Peeling & $3.75 \pm 3.4$ \\
& & Grading & $3.9 \pm 2.4$ \\
3 & Day and night shift (\%) & Setting & $2.81 \pm 2.14$ \\
& & Peeling & 32.0 \\
\multirow{2}{*}{4} & \multirow{2}{*}{ Work hours (hrs) } & Grading & 100 \\
& & Setting & 97.0 \\
5 & Respiratory discomfort & Day shift & 8.30 \\
& (Cold and frequent cough) (\%) & Day and night shift & 10.30 \\
& & Peeling & 50 \\
& & Grading & 62 \\
\end{tabular}




\section{Assessment of Total Immunoglobulin E}

Of the subjects who underwent Lung function test, willingness to participate for $\lg E$ estimation was sought. Necessary permission for carrying out this test was sought from the factory officials. However, many women workers did not willingly come forward for this test and hence only 50 women workers who were willing to participate in the study were selected from whom the blood samples were drawn for total IgE estimation. Out of this 50 , however, due to morbid fear of injection, one woman worker did not permit blood collection. Thus 49 subjects were examined for total immunoglobulin E (lgE). Total IgE (IU/ml) level was estimated by fully automated Bidirectionally Interfaced Chemi Luminescent Immuno Assay method. The normal level of Total IgE for adult woman is less than 150 $\mathrm{IU} / \mathrm{ml}^{12}$.

\section{Statistical analysis}

The analysis was done by Statistical Package for the Social Science (SPSS 16.0). Initially a descriptive analysis was done to observe the personal and occupational characteristics of the women workers. To assess whether there was a difference in the lung function of women workers in different sections, one-way ANOVA was used, and linear regression analysis was applied to obtain the association between total immunoglobulin $\mathrm{E}$ and static and dynamic parameters.

\section{RESULTS}

The fish processing task is predominantly performed manually. The fishes were washed in chlorinated water. Workers stand or sit on the floor to perform the activities in the seafood processing. The workers were employed in three sections namely peeling, grading and setting. The nature of activity in the peeling section was deveining shrimp, removal of head from shrimp, pulled vein shrimp, peeled and deveined shrimp, peeled and undeveined shrimp and cleaning of cuttlefish. Grading was categorising the type of seafoods into different varieties and grades which requires higher technical skills. Workers who were experienced in the seafood units were employed in this section. Setting section included preparation of final products such as individual quick freezing (IQF) of shrimp and cuttlefish, shrimp frozen and cuttlefish frozen and are packed as per the buyer requirements. The final products are packed in carton boxes. They were transferred to cold storage and subsequently dispatched to consignments.

Table 2: Static parameters (VC, IC and FVC) of lung function of women working in different sections

\begin{tabular}{|c|c|c|c|c|c|}
\hline \multirow{2}{*}{$\begin{array}{l}\text { S. } \\
\text { No }\end{array}$} & \multirow[t]{2}{*}{ Static parameters } & \multicolumn{3}{|c|}{ Sections $(N=105)$} & \multirow[b]{2}{*}{ F Value } \\
\hline & & $\begin{array}{c}\text { Peeling } \\
(\text { Mean } \pm S D) \\
(\mathrm{N}=\mathbf{2 8})\end{array}$ & $\begin{array}{c}\text { Grading } \\
\text { (Mean } \pm S D) \\
(\mathrm{N}=40)\end{array}$ & $\begin{array}{c}\text { Setting } \\
(\text { Mean } \pm S D) \\
(\mathrm{N}=37)\end{array}$ & \\
\hline \multirow[t]{4}{*}{1} & Vital Capacity (VC) & & & & \\
\hline & VC prediction (in litres) & $3.07 \pm 0.35$ & $2.98 \pm 0.44$ & $2.95 \pm 0.38$ & $0.649^{\mathrm{NS}}(\mathrm{P}=0.525)$ \\
\hline & VC actual value (in litres) & $1.77 \pm 0.48$ & $1.35 \pm 0.71$ & $1.64 \pm 0.42$ & $5.015^{\star \star}(P=0.008)$ \\
\hline & VC \% prediction & $58.79 \pm 17.58$ & $45.00 \pm 23$ & $55.92 \pm 13.31$ & $5.400^{\star \star}(P=0.006)$ \\
\hline \multirow[t]{4}{*}{2} & Inspiratory Capacity (IC) & & & & \\
\hline & IC prediction (in litres) & $1.87 \pm 0.25$ & $1.86 \pm 0.27$ & $1.84 \pm 0.24$ & $0.105^{\mathrm{NS}}(\mathrm{P}=0.900)$ \\
\hline & IC actual value (in litres) & $1.57 \pm 0.48$ & $1.15 \pm 0.66$ & $1.36 \pm 0.39$ & $5.119^{\star *}(P=0.008)$ \\
\hline & IC \% prediction & $85.39 \pm 29.58$ & $63.30 \pm 36.48$ & $73.73 \pm 19.56$ & $4.614^{*}(P=0.012)$ \\
\hline \multirow[t]{4}{*}{3} & Forced Vital Capacity (FVC) & & & & \\
\hline & FVC prediction (in litres) & $3.07 \pm 0.37$ & $3.01 \pm 0.40$ & $2.94 \pm 0.42$ & $0.835^{\mathrm{NS}}(\mathrm{P}=0.437)$ \\
\hline & FVC actual value (in litres) & $1.80 \pm 0.36$ & $1.63 \pm 0.39$ & $1.71 \pm 0.34$ & $1.642^{\mathrm{NS}}(\mathrm{P}=0.199)$ \\
\hline & FVC \% prediction & $59.00 \pm 12.15$ & $54.65 \pm 11.56$ & $58.62 \pm 11.72$ & $1.534^{\mathrm{NS}}(\mathrm{P}=0.221)$ \\
\hline
\end{tabular}

${ }^{\star *}-\mathrm{P}<0.01,{ }^{*}-\mathrm{P}<0.05, \mathrm{NS}-$ Non significant 
Table 1 represents the baseline information of the women workers. The mean age of the women workers in peeling, grading and setting included in the study were $19.57 \pm 3.31,18.60 \pm 3.23$ and $18.65 \pm 2.87$ years respectively. The mean work experiences of women working in peeling, grading and setting section were $3.75 \pm 3.4,3.9 \pm 2.4$ and $2.81 \pm 2.14$ years respectively. The work timings of the women workers were greatly dependent on the demand for the seafood during peak season. Hence the workers were allotted day or night shift based on the work load. However, 32 percent, 100 percent and 97 percent in peeling, grading and setting section of women workers were employed on day shift for a week and night shift for a week permanently. Those women workers who opted for day shift had to work from 8 am to $6 \mathrm{pm}$. Those who opted for two shifts that is day shift for a week ( 8 am to $8 \mathrm{pm}$ ) followed by night shift for a week had to work from $8 \mathrm{pm}$ to $8 \mathrm{am}$. Women workers from grading (62\%), setting (54\%) and peeling (50\%) section were reported respiratory discomfort during lung function test.

Table 2 presents the static parameters of lung function test results of women working in different sections. The women workers employed in peeling section had better percentage $(58.79 \pm 17.58)$ of predicted values of VC than those working in grading (45 \pm 23$)$ and setting sections (55.92 \pm 13.31$)$. IC results also indicated that peeling sections women

\section{Table 3: Dynamic parameters (FEV ${ }_{1}$, PEF and MEF $50 \%$ ) of lung} function of women working in different sections

\begin{tabular}{|c|c|c|c|c|c|}
\hline \multirow{2}{*}{$\begin{array}{l}\text { S. } \\
\text { No }\end{array}$} & \multirow[t]{2}{*}{ Dynamic parameters } & \multicolumn{3}{|c|}{ Sections $(N=105)$} & \multirow[b]{2}{*}{ F Value } \\
\hline & & $\begin{array}{c}\text { Peeling } \\
(\text { Mean } \pm S D) \\
(\mathrm{N}=28)\end{array}$ & $\begin{array}{c}\text { Grading } \\
\text { (Mean } \pm S D) \\
(\mathrm{N}=40)\end{array}$ & $\begin{array}{c}\text { Setting } \\
(\text { Mean } \pm S D) \\
(\mathrm{N}=37)\end{array}$ & \\
\hline \multirow[t]{4}{*}{1} & \multicolumn{5}{|c|}{ Forced Expiration Volume per second $\left(\mathrm{FEV}_{1}\right)$} \\
\hline & $\mathrm{FEV}_{1}$ prediction (in litres) & $2.66 \pm 0.34$ & $2.59 \pm 0.36$ & $2.54 \pm 0.38$ & $0.855^{\mathrm{NS}}(\mathrm{P}=0.428)$ \\
\hline & $\mathrm{FEV}_{1}$ actual value (in litres) & $1.72 \pm 0.48$ & $1.58 \pm 0.44$ & $1.69 \pm 0.35$ & $1.169^{N S}(P=0.315)$ \\
\hline & $\mathrm{FEV}_{1} \%$ prediction & $66.03 \pm 18.91$ & $60.47 \pm 15.97$ & $67.24 \pm 13.91$ & $1.899^{N S}(P=0.155)$ \\
\hline \multirow[t]{4}{*}{2} & Peak Expiratory Flow (PEF) & & & & \\
\hline & PEF prediction (in litres) & $6.17 \pm 0.66$ & $6.09 \pm 0.64$ & $6.03 \pm 0.88$ & $0.652^{N S}(P=0.523)$ \\
\hline & PEF actual values (in litres) & $4.93 \pm 1.25$ & $3.85 \pm 1.37$ & $3.92 \pm 1.57$ & $5.566^{\star *}(P=0.005)$ \\
\hline & PEF \% prediction & $80.18 \pm 20.49$ & $63.47 \pm 22.30$ & $67.54 \pm 28.81$ & $4.026^{*}(P=0.021)$ \\
\hline \multirow[t]{4}{*}{3} & \multicolumn{5}{|c|}{ Maximum Expiratory Flow (MEF 50 \% ) } \\
\hline & MEF 50\% prediction (in litres) & $4.07 \pm 0.47$ & $3.92 \pm 0.46$ & $3.80 \pm 0.56$ & $1.315^{\mathrm{NS}}(\mathrm{P}=0.273)$ \\
\hline & MEF $50 \%$ actual values (in litres) & $4.03 \pm 0.88$ & $3.23 \pm 0.99$ & $3.32 \pm 1.21$ & $5.435^{\star *}(P=0.006)$ \\
\hline & MEF $50 \%$ prediction & $101.71 \pm 23.09$ & $83.10 \pm 27.77$ & $88.92 \pm 33.73$ & $3.454^{*}(P=0.035)$ \\
\hline
\end{tabular}

${ }^{* *}-P<0.01,{ }^{*}-P<0.05$, NS-Non significant

Table 4: Distributions of women workers by their FEV

\begin{tabular}{lcc}
\hline FEV $_{\mathbf{1}}$ (\%) & Number=105 & Percent \\
\hline Above 80 (Normal) & 15 & 14.3 \\
50-80 (Moderate COPD) & 77 & 73.3 \\
30-50 (Severe COPD) & 10 & 9.5 \\
Below 30 (Very severe COPD) & 3 & 2.9 \\
\hline
\end{tabular}

COPD- Chronic obstructive pulmonary disease workers had higher percentage $85.39 \pm 29.58$ of prediction as against women working in grading (63.30 \pm 36.48$)$ and setting sections $(73.73 \pm 19.56)$. The analysis of variance also indicated that these static parameters differed among women working in different sections.

FVC is one the prime indicators of the lung function test. It gives a picture of the maximum volume of air exhaled with maximal force effort after maximum inspiration. The higher the FVC values 
Table 5: Influence of total IgE on static and dynamic parameters of lung function

\begin{tabular}{|c|c|c|c|c|c|}
\hline \multirow{2}{*}{$\begin{array}{l}\text { S. } \\
\text { No. }\end{array}$} & \multirow{2}{*}{$\begin{array}{l}\text { Static and } \\
\text { dynamic } \\
\text { parameters }\end{array}$} & \multicolumn{3}{|c|}{ Mean per cent of predicted values $(\mathrm{N}=49)$} & \multirow[b]{2}{*}{$\begin{array}{l}\text { Coefficient } \\
\text { value }\end{array}$} \\
\hline & & $\begin{array}{c}\text { Below } 150 \\
(\operatorname{lgE}(\mathrm{IU} / \mathrm{ml})) \\
\mathrm{N}=6\end{array}$ & $\begin{array}{c}150-300 \\
(\lg E(I U / m \mathrm{l})) \\
N=8\end{array}$ & $\begin{array}{c}\text { Above } 300 \\
(\operatorname{IgE}(\mathrm{IU} / \mathrm{ml})) \\
\mathrm{N}=35\end{array}$ & \\
\hline 1 & VC & $47.67 \pm 26.98$ & $41.3 \pm 27.42$ & $51.31 \pm 18.78$ & $0.426{ }^{\mathrm{NS}}(\mathrm{P}=0.158)$ \\
\hline 2 & IC & $67.17 \pm 41.01$ & $67.6 \pm 45.98$ & $66.51 \pm 28.31$ & $0.344^{N S}(P=0.250)$ \\
\hline 3 & FVC & $68.67 \pm 12.01$ & $53.8 \pm 11.37$ & $57.14 \pm 11.36$ & $0.510^{*}(P=0.013)$ \\
\hline 4 & $\mathrm{FEV}_{1}$ & $64.50 \pm 33.81$ & $62.0 \pm 13.38$ & $64.86 \pm 13.17$ & $0.466^{*}(P=0.040)$ \\
\hline 5 & PEF & $78.33 \pm 33.09$ & $73.25 \pm 14.66$ & $60.09 \pm 23.44$ & $1.599^{*}(P=0.036)$ \\
\hline 6 & MEF $_{50 \%}$ & $95.17 \pm 32.74$ & $89.12 \pm 19.79$ & $80.94 \pm 29.94$ & $0.692^{\mathrm{Ns}}(P=0.347)$ \\
\hline
\end{tabular}

*- $\mathrm{P}<0.05$, NS-Non significant

better is the air flow in the respiratory system. Analysis of FVC percentage of prediction indicated that women worker in peeling section had better percentage of prediction value of FVC $(59 \pm 12.15)$ followed by those working in setting section $(58.62 \pm 11.71)$ and grading section $(54.65 \pm 11.56)$. However, analysis of variance of FVC actual and percentage of prediction indicated that the variation between sections was not significant.

Table 3 presents the dynamic lung parameters in different sections. Analysis of the mean percentage of prediction value of $\mathrm{FEV}_{1}$, PEF and MEF ${ }_{50 \%}$ of women workers in the three sections revealed that women workers in setting section had better $F E V_{1}$ which was $67.24 \pm 13.91$ percent of prediction value, followed by peeling section with $66.03 \pm 18.91$ percent of $\mathrm{FEV}_{1}$ and grading sectionwith $60.47 \pm 15.97$ percent of $\mathrm{FEV}_{1}$. However, analysis of variance of $\mathrm{FEV}_{1}$ actual and percentage of predictionindicated that the variation in $\mathrm{FEV}_{1}$ between women workers in different section was not significant.

When comparing the percentage of prediction of PEF of women workers in the peeling, grading and setting sections, women workers in peeling section had better PEF $(80.18 \pm 20.49)$, followed by setting section workers $(67.54 \pm 28.81)$ and grading section workers $(63.47 \pm 22.30)$. The results indicated that women workers in peeling and setting section workers had better dynamic parameters such as FEV ${ }_{1}$ and PEF. Maximum expiratory at $50 \%$ of $\mathrm{FVC}$ is known as MEF ${ }_{50 \%}$ This also confirmed that women employed in peeling section had better MEF ${ }_{50 \%}$ as against their coworkers in other sections. The analysis of variance for PEF and MEF ${ }_{50 \%}$ actual and percentage of prediction for women workers in different sections was found to be significant.

Chronic obstructive pulmonary disease (COPD), also known as chronic obstructive lung disease (COLD) is the occurrence of chronic bronchitis or emphysema, a pair of commonly coexisting diseases of the lungs in which the airways narrow over time. This limits airflow to and from the lungs, causing shortness of breath. Lung function is associated with chronic obstructive pulmonary disease (COPD). Hence based on the FEV values $_{1}$ the women workers were as normal and classified as those having COPD at different levels.

Table 4 gives the distribution of women workers by their $\mathrm{FEV}_{1}$ classification. In the present study only 14.3 percent of women workers had normal level of more than 80 percent prediction value of $\mathrm{FEV}$. Almost 73 per cent of the women workers had moderate COPD, 10 percent of women workers had severe COPD and 3 percent of them had very severe COPD.

VC-Vital capacity, IC- Inspiratory Capacity, FVC- Forced vital capacity, FEV ${ }_{1}$-Forced Expiration Volume per second, PEF-Peak expiratory flow and $\mathrm{MEF}_{50 \%}$. Maximum Expiratory Flow. 
Total IgE and lung function parameters are tabulated and presented in Table5. Linear regression analysis between total IgE and static and dynamic parameters indicated that the dynamic parameters such as $\mathrm{FEV}_{1}$ and PEF were significantly associated with different levels of $\mathrm{IgE}$ and the same trend was observed in static parameters FVC.

\section{DISCUSSION}

In these industry women workers play an important role in quality control of the processed products and work in vital sections of the seafood industry. The mean work experience was more than two years indicating that women worked in these industries during their young age ((ie) before marriage) and later shifted from this job due to their marriage. During their young age, they were able to work for long hours with considerably higher speed when compared to their senior co-workers. As a result of their increased productivity, the younger women were preferred by the proprietors. Women were employed both during day and night shifts as per the job requirements. Since the harvested seafood products were received during late evenings, they had to be processed on the same night.

Static and dynamic parameters revealed that the women workers in grading section had lower level of actual values. This may be because that woman workers employed in grading section had long years of service in the industry and hence they were more exposed to seafood allergy. However the other reasons may be because, sixty two percent of workers in grading section had respiratory discomfort and all the workers in grading section had alternatively worked in day and night shifts and those who have opted alternate shift work had more work hours than day shift workers. These may be the probable reasons for the decreased lung function test. However, this needs to be validated on a larger sample to confirm the results. Majority of women workers in all the three sections had low level of static and dynamic parameters as against the predicted values. This may be due to the seafood allergy, severe cold, frequent cough and wheezing, accentuated by the work environment. The study indicated the need for the use of personal protective equipment such as disposable cloth face mask and the need for efficient ventilation in the work place. The lung function capacity parameters such as FVC and FEV 1 were significantly lower than predicted in fish processing workers. These findings indicated that fish processing workers were prone to developing acute and chronic respiratory symptoms as well as to lung function changes ${ }^{13)}$. The results of the present study are also similar. According to Bernstein and Malo ${ }^{14)}$ high molecular weight proteins present in aerosols were associated with the allergic respiratory symptoms. Occupational respiratory or rhinitis symptoms caused by inhalation of fish aerosols in trout-processing factory workers who worked next to an automatic gutting machine ${ }^{15)}$. High prevalence of work-related airway symptoms $(42.8 \%)$ in sea food industry workers due to the fish aerosols in the working place was reported by northern Norway seafood industry ${ }^{16)}$. The Norwegian salmon-processing workers and Russian trawler fishermen exhibit impaired respiratory health status compared to control populations without occupational exposure to fish ${ }^{17)}$. The major localized anaphylactic categories of IgE affect the respiratory tract that includes conjunctivitis, rhinitis, and asthma. After the interaction of antigen with cell-bound reagin, there is a release of certain mediators that cause vasodilation, hypersecretion, oedema and swelling of the respiratory mucosa. Since there is a continuity of the mucous lining membranes of all components of the respiratory tract, all components are adversely affected. The degree to which each target organ is affected will determine the clinical manifestation of the disease ${ }^{18)}$. All these studies advocate medical and technical preventive measures to be introduced in the work environment of the fish processing plant.

An increasing IgE value is due to the body's response to allergens which is manifested by sub optimum lung function. The static and dynamic parameters are indicators of the function of the respiratory system. As the level of total $\lg \mathrm{E}$ increased the values obtained for static and dynamic parameters of the women workers decreased. The reduction of predicted value due to total $\lg E$ is very well evident in PEF and MEF $_{50} \%$. Workers in grain storage godowns were grouped based on the IgE level as up to $250 \mathrm{IU} / \mathrm{ml}$ and above $250 \mathrm{IU} /$ $\mathrm{ml}$. The mean lung function test value was little higher among the workers whose IgE level was higher but the differences were statistically not- 
significant ${ }^{19}$. Occupational asthma was typically from an IgE mediated hypersensitivity reaction after respiratory exposure to aerosolised fish and shellfish proteins ${ }^{9}$.

\section{CONCLUSION}

The present study is an attempt to assess the lung function of women workers employed in seafood processing units. The study indicates a low level of static and dynamic parameters of lung function among the women workers. This may be due to the personal health condition, accentuated by the work environment. However the results of the study need to be carried out among large sample to validate the results. Though, based on this study preventive measure has been suggested to improve the health condition.

\section{ACKNOWLEDGEMENT}

We wish to acknowledge financial support received from University Grants Commission, New Delhi. The authors also wish to thank the seafood industry authorities and workers for their cooperation rendered to carry out the present study successfully.

\section{REFERENCES}

1. De Besche, A., On asthma bronchiale in man provoked by cat, dog, and different other animals. Acta Med Scand. 42: 237-55 (1937).

2. Jeebhay, M.F., Robins, T.G., and Lopata, A.L., World at work: fish processing workers. Occup Environ Med. 61(5):471- 474 (2004).

3. Jeebhay M.F., Robins T.G., Seixas N., Baatjies R., George D.A., Rusford E., Lehrer S.B., and Lopata, A.L.,Environmental exposure characterization of fish processing workers. Ann.Occup Hyg. 49(5):423-37(2005)

4. Douglas, J.D.M., McSharry C., Blaikie L., Morrow T., Miles S. and Franklin DO., Occupational asthma caused by automated salmon processing. The Lancet 346: 737-40 (1995)

5. Jeebhay, M.F., Robins, T.G., and Lehrer, S.B., Occupational seafood allergy-a review. Occup Environ Med. 58: 553-62 (2001).

6. Anupama, N., Sharma, M.V., Nagaraja, H.S., and Bhat, M.R., The serum immunoglobulin e level reflects the severity of bronchial asthma. Thai journal of physiological sciences. 18 (3):35-40 (2005)

7. Roitt, L., Brostoff, J. and Male, D., Immunology. 6th Ed, Harcourt Publisher, London, 324-445 (2001).

8. Gerrard, J.W., The biological importance of IgE. Immunol.Allergy Pract, 25: 381-84 (1984)

9. David, L., Raymond, L., Keith, B., Dominique,
J., Brice, L. and Jean-Ariel, D ., Occupational asthma in the commercial fishing industry: a case series and review of the literature. Int Marit Health, 61(1):13-17 (2010)

10. American Thoracic Society Statement on Standardisation of spirometry, Am Rev Res Dis 136, 86-96 (1987).

11. Celli, B.R., and MacNee, W., Standards for the diagnosis and treatment of patients with COPD: a summary of the ATS/ERS position paper. Eur Respir J. 23: 932-946 (2004).

12. Beeh, K.M., Ksoll, M. and Buhl, R.,Elevation of total serum immunoglobulin $E$ is associated with asthma in nonallergic individuals. Eur Respir J, 16: 609-614 (2000).

13. Zuskin, E., Kern, J., Mustajbegoviæ, J., Pucarincvetkoviæ, J., Jeliniæ, J.D. andBradiæ, T.,Respiratory symptoms in fish processing workers on the adriatic coast of Croatia. Arh Hig Rada Toksikol, 63: 199-205 (2012).

14. Bernstein, D.I., and Malo, J.L.,Highmolecular-weight protein agents, Asthma in the workplace, 2nd ed,24:445-456, Marcel Decker, New York. (1999).

15. Sherson, D., Hansen, I., and Sigsgaard, T.,Occupationally related respiratory symptoms in trout-processing workers. Allergy, 44: 336-41(1989)

16. Bang, B., Aasmoe, L., Aamodt, B.H., Aardal, L., Andorsen, G.S., Bolle, R., Boe, R., Vando, T., Evans, R., Florvag, E., Gram, I.T., Huser, P.O., Kramvik, E., Lochen, M.L., Pedersen, B. and Rasmussen, T., Exposure and airway 
effects of seafood industry workers in northern Norway. J Occup Environ Med, 47: 482-492(2005).

17. Shiryaeva, O., Aasmoe, L., Straume, B. and Bang, B.E., An analysis of the respiratory health status among seafarers in the Russian trawler and merchant fleets. Am J Ind Med, 54: 971-9.(2011).
18. Bellanti, J.A .,Immunology. III, 349-359, W B Saunders Company, USA(1985).

19. Chattopadhyay, B.P., Das, S., Adhikari, A. andAlam, J., Exposure to varying concentration of fungal spores in grain storage godowns and its effect on the respiratory function status among the workers. Ind Health, 45(3): 449-6. (2007). 